Rakenteiden Mekaniikka

Vol. 50, Nro 3, 2017, s. 153-157

https://rakenteidenmekaniikka.journal.fi/index

https://doi.org/10.23998/rm.23998/rm.65049

(CKirjoittaja(t) 2017.

Vapaasti saatavilla CC BY-SA 4.0 lisensioitu.

\title{
Kuormitustavan ja symmetrisyyden vaikutus kuormaa kantamattomien hitsausliitosten väsymiseen - tehollisen lovijännityksen ja murtumismekaniikan menetelmien vertailu
}

\author{
Antti Ahola ${ }^{1}$, Heli Mettänen ja Timo Björk
}

Tiivistelmä. Kasvavan taivutusjännitysosuuden (degree of bending, DOB) on ajateltu parantavan merkittävästi väsymiskestävyyttä perinteisessä jännitys-kestoikä (S-N) laskennassa. Tässä tutkimuksessa tarkasteltiin hitsattujen liitosten väsymistä kalvo- ja taivutuskuormituksessa tehollisen lovijännityksen menetelmällä ja lineaarielastisella murtumismekaniikalla. Tutkimuksen tuloksena saatiin selville, että liitoksen symmetrisyydestä määräytyen ulkoisen kuormituksen taivutusjännitys voi aiheuttaa merkittävästi korkeampia lovijännityksiä hitsin rajaviivalle kuin vastaavansuuruinen kalvojännitys.

Avainsanat: väsyminen, hitsatut liitokset, taivutus, liitoksen symmetrisyys

Vastaanotettu 22.6.2017. Hyväksytty 16.7.2017. Julkaistu verkossa 21.7.2017.

\section{Johdanto}

Useissa perusteoksissa on esitetty, että kasvava DOB parantaa väsymiskestävyyttä merkittävästi. Tätä perustellaan jännityksen keskiarvoistuksella pinnan läheisyydessä (ydintymisaika) sekä särönkasvun hidastumisella särön kärjen kasvaessa pienemmän jännitysgradientin alueelle. Tämä on otettu huomioon osassa hitsattujen liitosten väsymisohjeistuksia: BS7608:2014 [1] antaa yhdistetyn taivutus- ja paksuuskorjauskertoimen $k_{t b}$ ja DNV-GL [2] sallii 40 \% vähennyksen rakenteellisen jännityksen (hot spot, HS) taivutusjännitysosuuteen, kun jännityskonsentraatio on paikallinen ja särön kasvaessa tapahtuu kuormituksen uudelleenjakautuminen. Eurooppalaista väsymismitoitusta ohjaavissa Eurokoodi 3:ssa tai IIW:n ohjeistuksissa taivutuksen vaikutukseen ei kuitenkaan oteta kantaa [3,4].

${ }^{1}$ Vastuullinen kirjoittaja. antti.ahola@lut.fi 
Kasvavan DOB:n väsymiskestävyyttä parantavaa vaikutusta tukee myös olemassa olevat tutkimustulokset. Aiemmassa tutkimuksessa ulkoisen taivutuskuormituksen osoitettiin parantavan väsymiskestävyyttä selvästi verrattuna puhtaaseen kalvokuormitukseen [5]. Tätä tukee myös Kimin \& Yeongin [6], Baikin et al. [7] ja Maddoxin [8] tekemät tutkimukset. Toisaalta myös päinvastaisia tutkimustuloksia on esitetty [9].

Tarkasteltaessa ulkoisen kalvo- tai taivutuskuormituksen vaikutusta etenkin hitsattujen liitosten väsymiseen on syytä muistaa myös kuormitustyyppien periaatteelliset erot suhteessa tyypillisesti hitsatuissa rakenteissa esiintyviin kulma- ja sovitevirheisiin. Kalvojännityksessä kulma- tai sovitevirhe aiheuttaa sekundäärisen taivutusjännityskomponentin, kun taivutuskuormituksessa samanlaista lisäjännitystä ei synny. Tässä työssä on tarkasteltu erilaisten kuormaa kantamattomien liitosten väsymiskestävyyttä kalvo- ja taivutuskuormituksessa laskennallisesti sekä tehollisen lovijännityksen menetelmän (ENS) että lineaarielastisen murtumismekaniikan (LEFM) avulla.

\section{Elementtimenetelmät}

Tässä tutkimuksessa tarkastellaan kolmea eri kuormaa kantamatonta hitsausliitosta: poikittaista ripaliitosta, päällekkäisliitosta ja pitkittäistä ripaliitosta. 2D-liitoksista, Kuva 1a-b, tehdään puolimalli ja 3D-liitoksesta, Kuva 1c, tehdään neljännesosamalli symmetriareunaehtoja hyödyntäen. Tutkimuksessa varioidaan geometriamittasuhteita, kuten amittaa ja liitoslevyn paksuutta.

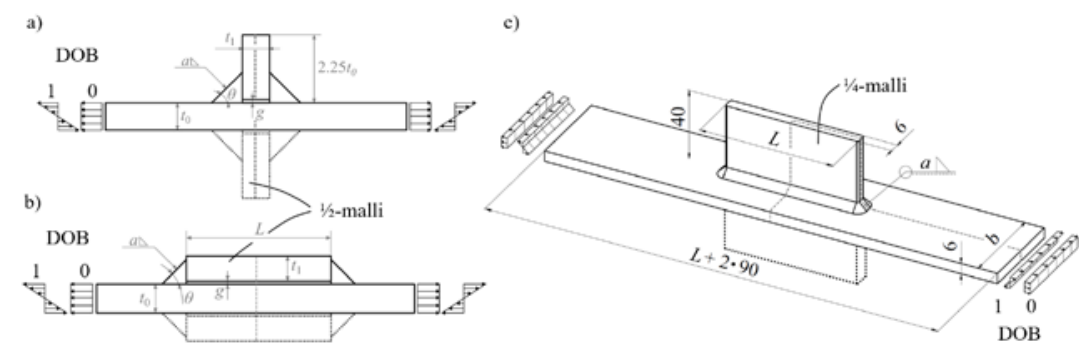

Kuva 1. Analysoidut liitostyypit: (a) kuormaa kantamaton poikittainen ripa, (b) päällekkäisliitos ja (c) kuormaa kantamaton pitkittäinen ripa.

2D-tasogeometriat analysoidaan käyttämällä tasovenymäelementtejä, ja 3D-liitokset solidielementtimalleilla ja alimallinnustekniikkaa hyödyntämällä, Kuva 2. ENSmalleissa rajaviivan pyöristyssäteenä käytetään $\rho=1 \mathrm{~mm}$, ja LEFM-malleissa alkusärökokona $a_{i}=0.05 \mathrm{~mm}$. 


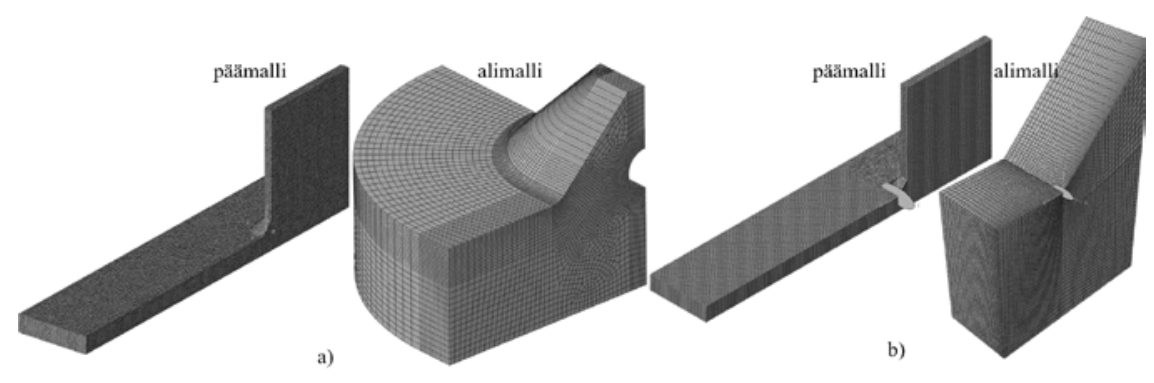

Kuva 2. Esimerkki 3D FE-malleista: (a) ENS-malli ja (b) LEFM-malli.

LEFM-malleista määritetään jännitysintesiteettikertoimen vaihtelu $(\Delta K)$ ja väsymiskestoikä lasketaan Parisin särönkasvulailla. ENS-malleissa referenssiväsymislujuutena käytetään FAT = 225 MPa pääjännityskriteerin mukaisesti, johon verrataan analyysien perusteella määritettyjä lovijännityksiä.

\section{Tulokset}

LEFM:Ilä ja ENS:llä määritetyt kestoiät muutettiin nimellisiksi väsymislujuuksiksi (FAT) vastaten kahta miljoonaa kuormanvaihtolukua. Kuormitussuhteen ( $\left.q_{\text {load }}\right)$ ja liitoksen symmetrisyyden ( $\left.q_{g e o m}\right)$ vaikutusta väsymislujuuksiin tarkastellaan suhteuttamalla lasketut väsymislujuudet seuraavasti:

$$
q_{\text {load }}=\frac{\mathrm{FAT}_{m}}{\mathrm{FAT}_{b}}
$$

ja

$q_{\text {geom }}=\frac{\mathrm{FAT}_{\text {asym }, i}}{\mathrm{FAT}_{\text {sym }, i}}$.

Yhtälössä (1) alaindeksit $m$ ja $b$ viittaavat kuormitustyyppiin, ( $m=$ kalvo ja $b=$ taivutus) ja yhtälössä (2) asym viittaa yksipuoliseen liitokseen (epäsymmetrinen) ja sym molemminpuoliseen liitokseen (symmetrinen). Kuvassa 3 on esitetty tulokset poikittaiselle rivalle. Kuvasta voidaan havaita, että laskennallisesti epäsymmetrisen liitoksen väsymislujuus oli huomattavasti parempi kalvokuormituksessa kuin symmetrisen liitoksen. Taivutuskuormituksessa symmetrisen liitoksen rajaviivalle syntyi vastaavasti pienempi lovijännitys ja näin ollen sen väsymislujuus oli parempi. Kalvokuormitus johti epäsymmetrisillä liitoksilla laskennallisesti parempaan väsymislujuuteen ja taivutuskuormitus symmetrisillä liitoksilla parempaan väsymislujuuteen. Muilla tarkastelluilla liitostyypeillä tulokset olivat yhtenevät. 


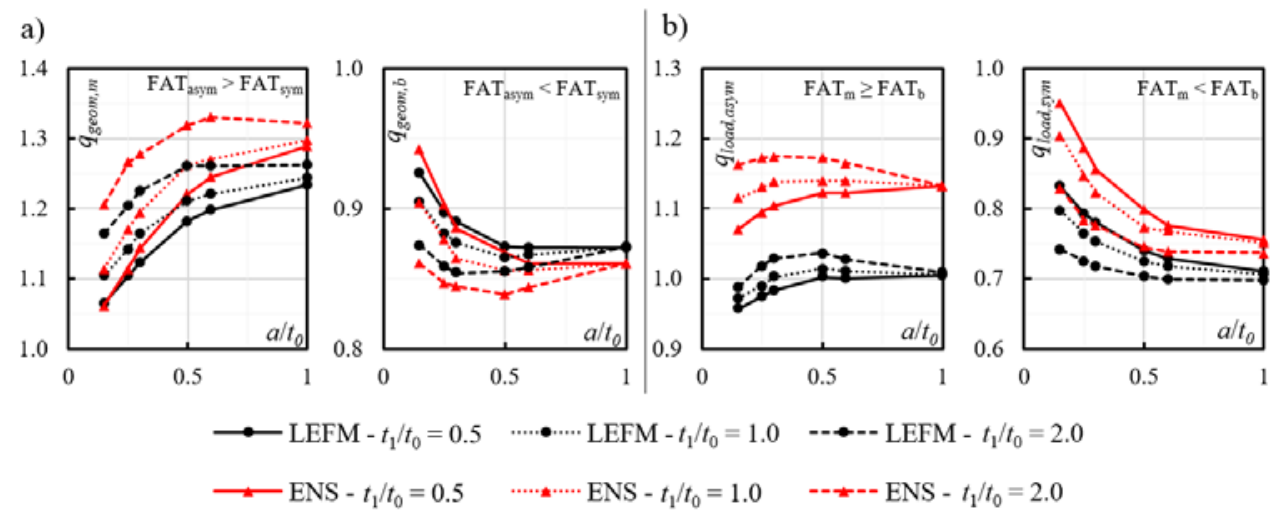

Kuva 3. Poikittaisen rivan tapaus: (a) symmetrisyyden vaikutus ( $\left.q_{\text {geom }}\right)$ eri kuormitustapauksille ja (b) kuormituksen vaikutus ( $\left.q_{\text {load }}\right)$ toispuolisilla ja molemminpuolisilla liitoksilla.

\section{Johtopäätökset}

Tehtyjen analyysien perusteella voidaan vetää seuraavat johtopäätökset:

- Taivutuskuormitus voi aiheuttaa merkittävästi korkeampia lovijännityksiä hitsin rajaviivalla kuin vastaava nimellinen kalvokuormitus, varsinkin liitoslevyn ollessa yksipuolinen. Useat koetulokset ovat kuitenkin osoittaneet, että taivutuskuormitus parantaa väsymislujuutta.

- LEFM:ssa lovijännitys määrää särönkasvunopeuden pienellä särökoolla $(a<$ $0.1 t$ ), mutta suuremmalla särökoolla kuormitustyyppi vaikuttaa enemmän särönkasvunopeuteen, ts. taivutuksella särönkasvunopeus on pienempi.

\section{Viitteet}

[1] BS7608:2014+A1:2015. Guide to fatigue design and assessment of steel products. British Standards, 2015

[2] DNVGL-RP-C203. Fatigue design of offshore steel structures. Det Norske Veritas - Germanischer Lloyd, 2016.

[3] EN 1993-1-9. Eurocode 3: Design of Steel Structures. Part 1-9: Fatigue. European Committee for Standardization, 2005.

[4] A. Hobbacher. Recommendations for fatigue design of welded joints and components, 2nd ed. Springer International Publishing, Cham, 2016

[5] A. Ahola, T. Nykänen \& T. Björk. Effect of loading type on the fatigue strength of asymmetric and symmetric transverse non-load carrying attachments. Fatigue and Fracture of Engineering Materials and Structures, 40:670-682, 2017. https://doi.org/10.1111/ffe.12531

[6] I. Kim I \& Y. Jeong. Fatigue Strength Improvement of Welded Joints by Blast Cleaning for Subsequent Painting. International Journal of Steel Structures, 13:11-20, 2013. https://doi.org/10.1007/s13296-013-1002-0 
[7] B. Baik, K. Yamada \& T. Ishikawa. Fatigue crack propagation analysis for welded joint subjected to bending. International Journal of Fatigue, 33:746758, 2011. https://doi.org/10.1016/j.ijfatigue.2010.12.002

[8] S.J. Maddox. Allowance for bending in fatigue design rules for welded joints. IIW-dokumentti XIII-2580-15, 2015.

[9] M. Ottersböck, M. Leitner \& M. Stoschka. Effect of loading type on welded and HFMI-treated T-joints. IIW-dokumentti XIII-2584-15, 2015.

Antti Ahola, Heli Mettänen, Timo Björk

Lappeenrannan teknillinen yliopisto

Skinnarilankatu 34, PL20, 53851, Lappeenranta

antti.ahola@lut.fi, heli.mettanen@lut.fi, timo.bjork@lut.fi 